\title{
Prohibition of Monopolistic Practices and Unfair Business Competition in Indonesia: A Legal Mechanism to Balance the Public Interest
}

\author{
Ni Luh Made Mahendrawati
}

Warmadewa University, Bali, Indonesia

\begin{abstract}
The study is to explore the legal mechanism of prohibition of monopolistic practices and unfair business competition in Indonesia by looking at the role of the Business Competition Supervisory Commission (KPPU). This study was conducted using the empirical normative method. In this context, the regulatory reference used is Law No. 5 of 1999 (Anti-Monopoly Law). Other regulations are Article 34 of Law No. 5 of 1999 and Presidential Decree No. 75 of 1999 and named the Business Competition Supervisory Commission (KPPU). Several KPPU decisions analyzed were in the cities of Medan, Semarang, Surabaya, Makassar and Central Jakarta. The results showed that Law No. 5 of 1999 regarding the Prohibition of Monopolistic Practices and Unfair Business Competition in Indonesia was formulated to the principle of balancing interests, namely the balance between the interests of business actors with the public interest. The formulation of the principle of balance can be found in the considerations, explanations and articles in Law No. 5 of 1999.
\end{abstract}

Keywords: Monopolistic Practices, Legal Procedures, Unfair Competition, Business Competition, Balance Principle.

\section{INTRODUCTION}

In the era of globalization and free trade as it is today, economic activity is becoming increasingly intense and broad-reaching all parts of the world and has a broad scope of human activity wherever located, distance and time are no longer a barrier to economic activity (Nakanishi, 2009; Shimomura, 2009). Economic globalization activities are manifested in various forms: liberalization of trade in goods and services, increasing migration temporarily or permanently, foreign direct investment by multinational companies, and standardization of various regulations. Furthermore, advances in communication and network technology provide faster and greater means of transporting goods, are easier to provide services, and are faster and clearer in conveying information. In the perspective of fair competition, economic activity is a series of activities that are simultaneous, comprehensive and continuous (Hartono, 2007; Toha \& Retnaningsih, 2020). Those who carry out economic activities are called economic actors, both individuals and groups or business entities. In general, economic activities can be classified into two main activities, namely producing goods and/or services. In general, all economic activities are divided into 2 categories, namely goods and services. Production of goods, including agriculture, mining, manufacturing, construction, etc. Each of these sectors produces material products. The service industry includes banking, communication,

*Address correspondence to this author at the Warmadewa University, Bali, Jl. Terompong No. 24, Sumerta Kelod, Denpasar, Bali 80239, Indonesia;

E-mail: mahendrawati.warmadewa@gmail.com computer software development, etc. (Encyclopædia Britannica, 2017), and activities to distribute goods and/or services from producers, intermediaries to consumers (Hübner, 2007). Furthermore, these two main activities can be reduced to various other fields of activity that are more detailed.

It must be recognized that economic activities cannot be separated from competition between business actors. This is a requirement for the implementation of a market economy. Moreover, in the global era that demands a free market economic system, so that competition between business actors will be more open. Sometimes the business competition is fair competition, but on the contrary, business actors can conduct the unfair competition in order to get the maximum profit. With regard to business competition law, in Law No. 5 of 1999 has established a body or commission called the Business Competition Supervisory Commission (KPPU) which is given such broad authority ranging from receiving reports on alleged monopolistic practices and or unfair business competition, summoning business actors, to deciding cases and imposing sanctions on businessmen), bearing in mind the provisions of procedural law that are specific in handling business competition cases. Furthermore, in the case of business competition as regulated in Law No. 5 of 1999 loaded with economic legal content, being on the same side of the judiciary as an institution that carries out the functions of the judiciary power is required to provide justice and legal certainty for all parties and the judge's decision must be able to provide balance and benefit 
for all parties, then in law enforcement business competition Judges are required to be able to understand the principles of economic law and general legal principles while at the same time creating balance through their decisions.

\section{LITERATURE REVIEW}

In the era of globalization, the demands and interests of the protection of members of the community in realizing the ideals of the welfare state require an increasingly extensive legislation regulation. In Neo-classical theory, demands for economic transformation are no longer merely pursuing growth, but furthermore, the transformation demanded and pursued is a scope of life that concerns the basic needs of global, regional and national societies that have dimensions (Harahap, 1995). The first is justice by developing patterns that can sustain the balance between too much and too little to consume the earth's power source. Thus, equitable distribution will be realized in the role of the economy as well as the control of resources and economic activities that are evenly distributed across all levels of society. Economic power is not concentrated centrally in the hands of a handful of people which creates inequality that destroys the ideals of the economic order of the self-government enterprise or a shared economy.

The second is the sustainability by increasing economic production results do not arbitrarily deplete the earth's resources and the ability of ecosystems. However, what is desired is that each generation recognizes the obligation to preserve the earth's resources and ecosystems as rights that must be maintained for the next generation. The third is the coverage by giving and opening opportunities as wide as possible for all levels of society to participate in the role of economic life to achieve welfare improvement. It is not just giving opportunities to small groups that are centralistic, which will cause social inequality and conflict.

The aspirations towards building a just, sustainable economy and the coverage demanded by the values of globalization require a variety of laws and regulations that are fast, in line with the very rapid changes in the global economy. In general, the law aims to create a balance of interests in the form of legal certainty so that proportional justice is born in a prosperous society (Hartono, 2007). The balance function also includes the structure of the economic life of the community in order to meet their needs. The balance order is very important to be realized in the economic order in the form of laws and regulations. For Indonesia, the legal order must be based on the values of the Pancasila and the 1945 Constitution as a basic norm that serves as the highest source of law. These principles of law should be absorbed and placed in the provisions of the laws and regulations in Indonesia, both directly stated in the articles, as well as the principles and objectives of these regulations. Thus, it can be expected that the law will be able to function in realizing a just and prosperous society or at least achieving a balance of interests in society.

\section{METHOD}

This study was conducted using the empirical normative method. Normative-empirical legal research (applied law research) is research that uses normativeempirical legal case studies in the form of legal behavior products. This study analyzes regulations related to monopolistic practices and unfair business competition in Indonesia and analyzes various KPPU decisions related to monopolistic practices in several cities in Indonesia.

This normative-empirical legal research method is basically a combination of the normative legal approach with the addition of various empirical elements. This normative-empirical research method, it is also about the implementation of normative legal provisions (laws) in their actions in every particular legal event in society. In this context, the regulatory reference used is Law No. 5 of 1999 (Anti-Monopoly Law). Other regulations are Article 34 of Law No. 5 of 1999 and Presidential Decree No. 75 of 1999 and named the Business Competition Supervisory Commission (KPPU). Several KPPU decisions analyzed were in the cities of Medan, Semarang, Surabaya, Makassar and Central Jakarta. The data analysis technique was carried out using descriptiveanalytical methods by referring to various reports and secondary data regarding cases handled by KPPU and bankruptcy. The analysis is also based on examples of data regarding the pricing of basic needs in the form of gas by the state gas company. Therefore, the judicial case study approach is used as an analysis in this study as a legal case study in the context of antimonopoly and sound business practices. This is because of the conflict so that it will involve the interference of courts and the anti-monopoly commission in Indonesia to be able to provide resolution decisions regarding cases of monopoly, bankruptcy, pricing and fair competition. 


\section{RESULTS}

Regarding KPPU's role in enforcing Competition Law in Indonesia is that it is to oversee the implementation of Law No. 5 of 1999 (Anti-Monopoly Law) where the Commission was formed. This establishment is based on Article 34 of Law No. 5 of 1999 which instructed that the formation of the organizational structure, duties and functions of the commission be determined through a Presidential Decree. This commission was then formed based on Presidential Decree No. 75 of 1999 and named the Business Competition Supervisory Commission (KPPU).

Therefore, Anti-Monopoly law enforcement and business competition are under the authority of the KPPU (Putri \& Prananingtyas, 2020; Lee, 2015; Maarif, 2004; Wahyuningtyas, 2016). However, this does not mean that there are no other institutions authorized to handle monopoly and business competition matters. The District Court and the Supreme Court were also given the authority to settle the case. The District Court was given the authority to handle objections to the KPPU's decision and deal with violations of competition law which became a criminal case because KPPU's decisions were not carried out permanently. The Supreme Court is authorized to settle cases of violation of competition law in the case of an appeal against the district court decision. As an independent institution, it can be said that the authority possessed by KPPU is very large which includes the authority possessed by the judiciary. This authority includes investigations, prosecutions, consultations, examining, adjudicating, and deciding cases.

In the context of constitutional law, KPPU is a state auxiliary organ that has the authority under Law No. 5 of 1999 to enforce business competition law. A simple state auxiliary organ is a state institution formed outside the Constitution and is an institution that helps carry out the duties of the main state institutions (executive, legislative, and judiciary) which are often also referred to as quasi-independent state institutions

Table 1: Postponement of Debt Payment Obligations and Bankruptcy Cases

\begin{tabular}{|c|c|c|c|c|}
\hline \multirow{2}{*}{\begin{tabular}{|c|} 
Commercial Court \\
\cline { 2 - 5 }
\end{tabular}} & Semester I 2019 & Semester I 2020 & Semester I 2019 & Semester I 2020 \\
\hline \hline Medan & 14 & 14 & 3 & 12 \\
\hline Semarang & 7 & 16 & 16 & 2 \\
\hline Surabaya & 24 & 36 & 2 & 4 \\
\hline Makassar & 6 & 1 & 43 & 76 \\
\hline Central Jakarta & 112 & 249 & 47 \\
\hline
\end{tabular}

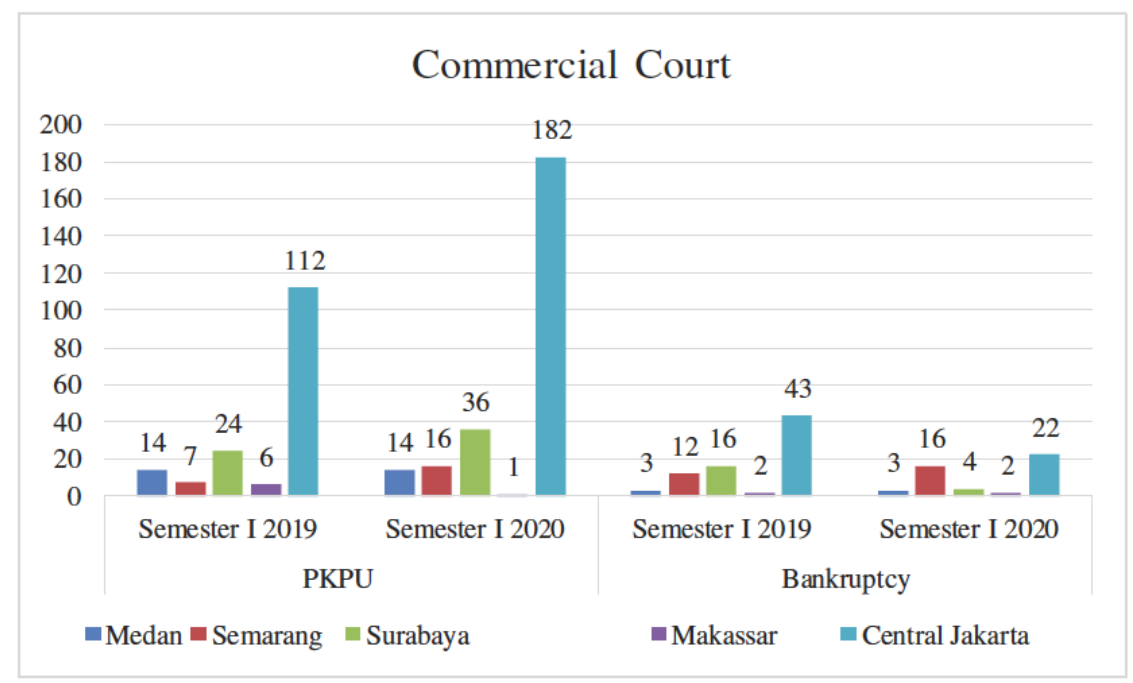

Figure 1: Number of the postponement of debt payment obligations and bankruptcy cases. 
(Risnain, 2018). The role of a quasi-independent state institution becomes important as a responsive effort for countries that are transitioning from authoritarianism to democracy (Kagramanto, 2007).

KPPU's position in fuel subsidies can be an example in this context (Iwantono, 2003). As understood, Law No. 22 of 2001 regarding Oil and Gas amended by the Constitutional Court ordered the government to regulate prices not limited to subsidized fuel. KPPU is in a position to support subsidies while asking that the government set limits on the price of non-subsidized fuel so that the competitive landscape is that subsidized fuel is available, while nonsubsidized fuel is affordable. Business actors compete for the market (tenders to become subsidized fuel suppliers) and in the market (head-to-head competition) in the range below the upper limit price for non-subsidized fuel. In other words, KPPU is not antisubsidized. However, it has a hard position when subsidies are used as weapons to blackmail people with the mode of reducing subsidized goods. The aim is to condition the people to buy non-subsidized goods which are first reduced by volume and raised in price. It is very clear that if nationalism is interpreted as the spirit of subsidies to help the people's low purchasing power, then KPPU is one of the pillars of this (Widiyanti et al., 2019; Wahyuningtyas, 2014; Simbolon, 2019; Wattegama et al., 2008). As a role of KPPU in providing fair pricing, the findings of this study showed the adjustments to the Decree of the Board of Directors of PT Perusahaan Gas Negara (Persero) Tbk. No. 006904.K/HK.00.01/UT/2013 dated July 31, 2015, concerning Gas Prices in Business Entity Certificate in Distribution Region III for Service and Commercial Industry Customers as well as Manufacturing and Power Generation Industry Customers are in Table 2.

President with the approval of the DPR appointed KPPU members in carrying out their duties are responsible to the President. This is in line with practice in the USA where the FTC is responsible to the President. This provision is reasonable because KPPU carries out part of the duties of the government, while the highest authority of the government is under the President. Nevertheless, it does not mean that KPPU in carrying out its duties cannot be free from government interference. Independence is still maintained by the involvement of the DPR to participate in determining and controlling the appointment and dismissal of KPPU members. Besides the duties and authority possessed by KPPU which is so important, in reality, KPPU still experiences obstacles in carrying out its duties. These constraints cause KPPU to not be able to carry out their duties optimally. For instance, KPPU has the authority to conduct research and investigation, but KPPU does not have the authority to conduct searches on business actors who are indicated to have violated Law No. 5 of 1999. In conducting research and investigations, KPPU is often constrained by the nature of company confidentiality, so that KPPU cannot obtain data the company needed. Although KPPU is authorized to request information from Government agencies, up to now there has not been a good collaboration between KPPU and government agencies in the matter of investigating allegations of unfair business competition. As a result, KPPU often experiences difficulties in carrying out their duties due to lack of supporting data. In addition, KPPU is authorized to summon business actors or witnesses, but KPPU cannot force their presence. The existence of these obstacles resulted in the Commission not being able to optimally exercise its authority. In addition to overcoming the problems above, the challenge that must be answered next is to clarify the institutional status of KPPU in the constitutional system. This is important because the unclear status of the KPPU in the constitutional system makes this Commission vulnerable to debate its existence, especially when this commission carries out its duties and functions.

\section{DISCUSSION}

Regarding the principle of business competition balance in the framework of Indonesian nationalism,

Table 2: Price Adjustment of Gas by KPPU

\begin{tabular}{|c|c|c|c|c|}
\hline No. & Price Classification & Enforcement & Amount & Surcharge provisions \\
\hline 1. & P0 & 1 August 2015 & IDR $7.400 / \mathrm{m}^{3}$ & $120 \%$ \\
\hline 2. & $\mathrm{P} 1$ & 1 August 2015 & IDR 167.600/MMB TU + IDR770/ $\mathrm{m}^{3}$ & $120 \%$ \\
\hline 3. & $\mathrm{P} 2$ & 1 August 2015 & IDR 167.600/MMB TU + IDR 750/ $\mathrm{m}^{3}$ & $120 \%$ \\
\hline 4. & General Price & 1 August 2015 & IDR 167.600/MMB TU + IDR 850/ $\mathrm{m}^{3}$ & $120 \%$ \\
\hline
\end{tabular}

Source: Case Decision of No. 09/KPPU-L/2016. 
the question that is often raised by the public is, is healthy competition in accordance with the personality of the nation which has a family economic philosophy? Some even think that the competition values as regulated in Law No. 5 the Year 1999 concerning Prohibition of Monopolistic Practices and Unfair Business Competition (Competition Law) and the Business Competition Supervisory Commission (KPPU) as their supervisory institutions are entrusted by the IMF, entrusted by neo-liberal, exploitative neoliberal organizations. competition, anti-subsidies and anti-national interests.

This mindset is not wrong if it is related to the time of enactment of Law and KPPU in 1999 which coincides with the early years of the effectiveness of the IMF Letter of Intent (Lol). However, when examined further, it appears that the desire to have instruments and policies that are pro-healthy competition and anticonglomerate business structures were actually declared 10 years earlier by the people through the MPR as in the 1988 regulated Economic Policy Direction which outlines: (1) developing a populist economic system that relies on fair market mechanisms with the principles of fair competition; (2) avoiding monopolistic market structures; (3) optimizing the role of government in correcting market imperfections by removing all obstacles that interfere with market mechanisms. This determination was further strengthened by MPR Decree No. 10 of 1998 which was alarming, namely the implementation of the national economy which lacks the mandate of Article 33 of the 1945 Constitution and tends to show a very monopolistic style. This constitutional document shows that competition and KPPU are actually the culmination of the desires of the Indonesian people themselves who were dissatisfied with past business patterns and economic structures. The DPR responded by making the Competition Law the first initiative in the legislation history. So, commitment with the IMF turned out to be only a stimulant that accelerated the realization of this desire.

If nationalism is defined as a determination to protect national interests in the sense of the interests of small businesses and cooperatives, then this law has fulfilled them. Article 50 excludes the Act on small business operators and cooperatives. The law does not exclude business behaviour, but rather excludes its subjects, namely small businesses and cooperatives (Juwana, 2002; Fox, 2000). This can be interpreted as the commitment of the state through the Act, as in Article 3 regarding the objectives, namely to create a conducive business climate through a fair business competition arrangement so as to ensure the certainty of equal business opportunities for large business actors, medium business actors and small business actors. With this exception, the law respects the conditions and efforts of the sustainable small businesses and cooperatives that dominate our national business actors (Roisah et al., 2018; Pangestu et al., 2002).

Competition policy includes enforcement and regulation or government policy (Wibowo et al., 2019). If the KPPU sees that a sector is too strategic to be released from the competition, due to technical reasons or the high concentration of product characteristics due to the lack of investment, the KPPU will advise the government to regulate it (Faujura et al., 2021). If a product requires subsidies due to the low purchasing power of the people, the KPPU asks the government to give it. Furthermore, if nationalism is also interpreted as SOE control over the strategic business sector and the maximum limit of foreign ownership in certain businesses, then KPPU will not sue it. Even Article 51 of the Law justifies SOEs controlling strategic sectors as respected natural monopolies, provided they do not abuse them. The same thing is also done if the law or the government issues an upper limit or even closes on foreign ownership, the KPPU will always respect it as long as it is consistently regulated. If this happens, KPPU will guarantee fair competition between domestic business actors without discrimination. As a result, fair competition is the identity of the Indonesian people. It contains a stimulant to compete towards a business structure that is not monopolistic. Ideally, fair competition is aimed at increasing consumer and producer welfare by reducing deadweight loss (economic inefficiency factor).

\section{CONCLUSION}

The results of the study show that Law No. 5/1999 is formulated on the principle of a balance of interests, namely the balance between the interests of business actors and the public interest. The formulation of the principle of balance can be found in considerations, explanations and articles in Law Number 5 of 1999. In this context, business actors are prohibited from entering into agreements with other business actors to jointly control the production and or marketing of their products and/or marketing. goods and or services that may result in monopolistic practices and or unfair business competition. 
In the realization, of the principle of balance of interest in Law No. 5 of 1999 does not yet reflect proportional equity to carry out the role of the economy and control of resources and economic activities so that it has not fully implemented the principle of economic democracy by taking into account the balance of interests. The principle of balance includes the balance between business people and the public interest. For this reason, the balance which was conducted by KPPU must refer to the laws and regulations with values of justice that are recognized in society. As a practical implication, in applying balance, the judge in the decision is based on the principles, aims and objectives of Law No. 5 of 1999, namely maintaining public interest and increasing national economic efficiency as an effort to improve people's welfare. Lastly, the conclusion mainly highlights that Competition Law is a synthesis of two diametric points, namely free fight liberalism which adheres to unlimited competition and statism which prioritizes state ownership and control in the economy. Competition law is a bridge that guarantees competition in regulatory corridors, and in Indonesia, this role was conducted by KPPU to oversee the monopolistic practices and unfair business competition.

\section{REFERENCES}

Encyclopædia Britannica. (2017). Service industry. Retrieved from https://www.britannica.com/topic/service-industry, February 25, 2017.

Faujura, R.P., Gultom, E., \& Sudjana, S. (2021). The Monopoly Practice and Unfair Business Competition in the Technology Transfer Activity Through the Foreign Patent in Indonesia. UUM Journal of Legal Studies 12(2), 69-91. https://doi.org/10.32890/uumils2021.12.1.4

Fox, E. M. (2000). Equality, discrimination, and competition law: Lessons from and for South Africa and Indonesia. Harv. Int'I. LJ, 41, 579.

Harahap, M. Y. 1995. Development of Permanent Jurisprudence. Mimbar Hukum 16(5).

Hartono, S. R. (2007). Indonesian Economic Law. Bayumedia Pub.

Hübner, R. (2007). Strategic supply chain management in process industries: An application to specialty chemicals production network design (Vol. 594). Springer Science \& Business Media. https://doi.org/10.1007/978-3-540-72182-6

Iwantono, S. (2003, October). Economic Crisis and Cartel Development in Indonesia. In 5th International Cartels Workshop (pp. 1-3).

Juwana, H. (2002). An Overview of Indonesia's Antimonopoly Law. Wash. U. Global Stud. L. Rev., 1, 185.

Kagramanto, B. L. (2007). Implementation of Law No. 5 of 1999 by KPPU. Jurnal Ilmu Hukum Justitia.
Lee, A. (2015). Onwards and upwards for Indonesian antitrust. International Financial Law Review.

Maarif, S. (2004). Competition Law in Indonesia: experience to be taken for the development of Competition Law in China. Wash. U. Global Stud. L. Rev., 3, 333.

Nakanishi, N. (2009). Successive Expansion and Stability of Network Integration in International Trade. In International Trade and Economic Dynamics (pp. 161-185). Springer, Berlin, Heidelberg. https://doi.org/10.1007/978-3-540-78676-4 15

Pangestu, M., Aswicahyono, H., Anas, T., \& Ardyanto, D. (2002). The evolution of competition policy in Indonesia. Review of Industrial Organization, 21(2), 205-224. https://doi.org/10.1023/A:1019633829374

Putri, P. K., \& Prananingtyas, P. (2020). Supervision of kppu on the action of mergers done by mining companies. Diponegoro Law Review, 5(1), 108-123.

https://doi.org/10.14710/dilrev.5.1.2020.108-123

Risnain, M. (2018). Eksistensi Lembaga Quasi Judisial Dalam Sistem Kekuasaan Kehakiman Di Indonesia: Kajian Terhadap Komisi Pengawas Persaingan Usaha. Jurnal Hukum dan Peradilan, 3(1), 49-58.

https://doi.org/10.25216/JHP.3.1.2014.49-58

Roisah, K., Utama, Y.J., Saraswati, R., \& Whidari, Y. (2018). Status and contemporary development of employee inventions ownership in G-20 countries. European Research Studies Journal, 21(2), 214224.

https://doi.org/10.35808/ersj/996

Shimomura, K. (2009). International trade and economic dynamics: essays in memory of Koji Shimomura. Springer

Simbolon, A. (2019). Prevention of monopolistic practices and unfair Business Competition through business Competition Supervision. Journal of Legal, Ethical and Regulatory Issues 22(1).

Toha, K., \& Retnaningsih, S. (2020). Legal policy granting status of fresh start to the individual bankrupt debtor in developing the bankruptcy law in Indonesia. Academic Journal of Interdisciplinary Studies, 9(2), 157-161. https://doi.org/10.36941/ajis-2020-0033

Wahyuningtyas, S. Y. (2014). Challenges in Combating Cartels, 14 Years After the Enactment of Indonesian Competition Law. Yearbook of Antitrust and Regulatory Studies (YARS), 7(10), 279-306. https://doi.org/10.2139/ssrn.2741622

Wahyuningtyas, S. Y. (2016). The online transportation network in Indonesia: A pendulum between the sharing economy and ex ante regulation. Competition and Regulation in Network Industries, 17(3-4), 260-280. https://doi.org/10.1177/178359171601700304

Wattegama, C., Soehardjo, J., \& Kapugama, N. (2008). Telecom Regulatory and Policy Environment in Indonesia Results and Analysis of the 2008 TRE Survey. Available at SSRN 1554762. https://doi.org/10.2139/ssrn.1554762

Wibowo, Y. S., Luddin, M. R., \& Sari, E. (2019). Understanding Organizational Commitments in the Public Sector: A Case Study of Commissioners and Investigators at The Business Competition Supervisory Commission (KPPU). Policy \& Governance Review, 3(3), 208-224. https://doi.org/10.30589/pgr.v3i3.152

Widiyanti, R., Hidayat, N. N., Setianto, N. A., Mastuti, S., \& Muatip, K. (2019, November). Vertical Integration of Broiler Industries in Indonesia (Analysis of Case Decisions No. 02/KPPU-I/2016). In IOP Conference Series: Earth and Environmental Science (Vol. 372, No. 1, p. 012005). IOP Publishing. https://doi.org/10.1088/1755-1315/372/1/012005

Received on 16-03-2021

https://doi.org/10.6000/1929-4409.2021.10.120

(c) 2021 Ni Luh Made Mahendrawati; Licensee Lifescience Global.

This is an open access article licensed under the terms of the Creative Commons Attribution Non-Commercial License (http://creativecommons.org/licenses/by-nc/3.0/) which permits unrestricted, non-commercial use, distribution and reproduction in any medium, provided the work is properly cited. 